\title{
Challenging the Advanced First-Year Student's Learning Process through Student Presentations
}

\author{
Lisa C. Kaczmarczyk \\ Sixth College, 0054 \\ University of California San Diego \\ 9500 Gilman Drive \\ La Jolla, CA. 92093 - 0054 USA \\ lisak@acm.org
}

\author{
Matthew R. Boutell \\ Computer Science and Software \\ Engineering \\ Rose-Hulman Institute of Technology \\ 5500 Wabash Ave. \\ Terre Haute, IN 47803 USA \\ boutell@rose-hulman.edu
}

\author{
Mary Z. Last \\ Business Information Technology and \\ Systems \\ University of Mary Hardin-Baylor \\ 900 College Street \\ Belton, TX 76513 USA \\ mlast@umhb.edu
}

\begin{abstract}
The decline in computing enrollments is a global concern that necessitates that every potentially successful computing student be targeted for support and development. The needs of technically experienced, highly capable first-term college students are unique, and no less challenging than the needs of their lesser-prepared peers. In order to attract advanced first-year students to further computing studies, we need to understand better how instruction can meet their needs. This paper reports the results of a study in which advanced first-term computing students were challenged to become in-depth researcher-learners and to teach the content they acquired to their peers. The results demonstrate that students and instructors alike perceive that the students made significant improvements in communication, presentation, and teaming skills and acquired deep content knowledge from their experience in the course. The data also show that students were extremely uncomfortable with the paradigm shift in their learning environment. These results suggest that anxiety-reducing changes are needed for the course, but that overall, the teacher-researcherlearner concept is very beneficial for increasing the understanding and learning of advanced first year computing students.
\end{abstract}

\section{Categories and Subject Descriptors}

K.3.2 [Computers And Education]: Computer and Information Science Education - computer science education, curriculum.

\section{General Terms}

Experimentation, Human Factors

\section{Keywords}

Communication, Advanced Students, Peer Learning

\section{INTRODUCTION}

It has been well accepted by the Computer Science Education community that communication, presentation, teamwork and critical thinking skills are necessary yet difficult challenges for

\footnotetext{
Permission to make digital or hard copies of all or part of this work for personal or classroom use is granted without fee provided that copies are not made or distributed for profit or commercial advantage and that copies bear this notice and the full citation on the first page. To copy otherwise, or republish, to post on servers or to redistribute to lists, requires prior specific permission and/or a fee.

ICER'07, September 15-16, 2007, Atlanta, Georgia, USA.

Copyright 2007 ACM 978-1-59593-841-1/07/0009...\$5.00.
}

many of our students [7][31]. Many studies have addressed one or more of these issues [19][22][25][26][30]. In addition, researchers with widely varied perspectives have investigated the challenges of teaching the first college computer course [3][13][18][27]. Results of these studies have generally emphasized the needs of a diverse student body, and often target reforms at helping the least well prepared students.

Previous studies have contributed to our understanding of college computing students in many ways, but they often have neglected an important group of learners: the advanced first-year computing student. A small but important group of students enter our programs with significant experience in computing. Unfortunately, many choose to pursue another field of study either immediately, or after experiencing their first year of course work. This phenomenon is part of the aptly-named "crisis in computing" [9], where highly qualified students pursue studies in other sciences, engineering or mathematics [8]. The computing enrollment problem is an international issue and thus has global economic consequences [14]. Thus, it is important that we investigate how to motivate and retain those students who begin their college career with both an interest in computing and extensive prior experience.

The primary goal of this paper is to present the results of a study targeted at advanced computing students in their first term of college. The study participants comprise an ideal population for this investigation. They attend a selective engineering and science college, and are well prepared in all the "traditional" ways: they have a strong mathematics background, extensive prior computing experience, and high expectations for their future success as technical professionals. However, internal institutional data shows that many of them choose not to major in computing.

This paper presents results of a study in which advanced introductory computing students are placed in a class that challenges their preconceived ideas about passive classroom learning. Students must become both teachers and active learners, developing research, communication, and teaming skills. Success will come only to those students who are able to become critical thinkers and self-directed researcher-learners. In particular, this study shows that students believe they learned far more from developing complex teaching modules known as "capsules" than they would have in a traditional lecture environment. Instructors' opinion concurs with student perception: capsule development caused students to become creative, self-directed learners. Results also show that students and instructors perceive notable improvement in students' communication, presentation and 
teaming skills. However, the study also revealed that students were very uncomfortable with the new approach to learning, which decreased their motivation towards studying computing. Instructors did not pick up on the strength of negative student feelings during classroom interactions, in spite of daily close instructor-student communication. This mix of positive and disappointing results provides insight into the challenges and promise unique to teaching advanced computing freshmen, and provides a springboard for changes needed to make this process more successful in the future.

\section{BACKGROUND}

College and university educators know instinctively what psychological researchers know empirically: teaching improves the understanding of the teacher [2][4][12]. In fact, many pedagogical researchers have reported successful efforts to enhance student learning through peer teaching as we will now discuss.

The positive results of peer teaching have been studied in a variety of settings. For example, Ching, et al. [10] explored the effect on motivation and other potential benefits of student tutors and their tutees. All were graduate students enrolled in the same course. The tutors had to study an assigned topic in depth, absorb it, and then teach it to one of their peers. Tutors developed their own instructional materials, which were evaluated anonymously by their peers. All students had to answer the same set of instructor-supplied questions after each teaching session. A key finding of this work was that strong bonds developed between tutors and tutees, and among the class as a whole. This bonding led to increased intrinsic motivation towards all aspects of the class. Tutors were concerned with, and felt responsible for, their tutees' progress. This enthusiasm rubbed off on the tutees, increasing their motivation as well. Tutors noted that the time commitment necessary to prepare good teaching materials was high, yet valuable for their own learning. A critical success factor identified in this study appears to have been the personal relationships formed between tutor and tutee; a secondary important factor was the overall structure provided by the instructor in delineating expectations.

Plimmer and Amor [24] required students to research course topics to a depth well beyond what the instructor covered in class. As with the Ching, et al. study [10], the students had to teach their peers, but as part of a large-scale project in human-computer interaction (HCI). Teams were intentionally created from students with heterogeneous prior knowledge in a wide range of fields, and the project required knowledge by all members in each of these areas. Results showed that students enjoyed working with their teammates, and found the time requirements for teaching quite high, but beneficial to their understanding of the HCI course material. On the other hand, there was little enthusiasm for the field of psychology, an important HCI area of knowledge. This surprising result reflects a common difficulty instructors have when they incorporate non-technical material into a computing course: students perceive "soft skills" as less relevant for their learning.

Dankel and Ohlich [11] developed an elective Artificial Intelligence course combining many of the beneficial aspects of the studies just described. A primary goal of the course was to address deficiencies in student presentation and oral communication skills. Students were placed into groups and assigned content topics to research and to formally teach the rest of the class. The instructor provided extensive instruction on presentation guidelines, good pedagogy, and peer evaluation techniques. Student reactions to the course were mixed. Overall they enjoyed the course and material. They were neutral about the benefits of their team experience researching and preparing teaching materials. However, they felt that their presentation abilities improved greatly, and they would recommend others to take the course. A key factor in the overall success of this course appears to have been the significant structure and guidance provided by the instructor.

As is clear from the preceding discussion, many studies of peer tutoring and advanced content learning take place with elective courses or with students advanced in their computing programs. Less work on these topics has been done at the entry levels of the computing curriculum. However, as noted by Carbone [6], Bruce [5], and Roberts [28], the challenges of motivating and retaining highly skilled, intelligent computing freshman are difficult and unique. Given the shrinking enrollments in computing programs in much of the world, these students need to be encouraged to persist in the major. Unfortunately, their needs are often at odds with the needs of other first term students - in part because their content knowledge is not a primary concern [5][6][28]. There are dangers for all first year students if the advanced and novice students share the same class - one group may well be neglected.

Some studies have explicitly addressed the challenges of teaching advanced first year students. For example, Carbone [6] reported that advanced first year students who participated in a selfdirected large project increased their intrinsic motivation, content knowledge and positive perceptions of computing over equally qualified students who did not participate in the project. One limitation of this study however, was that participation in the project was optional and a self-selection bias may have influenced the results.

Bruce [5], as part of an NSF-funded study, developed a separate course to address the unique challenges of teaching experienced computing freshmen. He demonstrated that these students could enjoy and absorb highly advanced course material. He also found that students in an advanced first course could integrate back into the curriculum for the second course at no detriment to themselves or other students. Finally, the study reported increased persistence in the computing major among students who participated in the advanced course, as compared to similar students prior to the offering of the course.

Roberts [28] described a decade's experience working at several institutions to motivate and maintain advanced first-term computing students. He strongly advocates minimizing the range of background and interest level in a particular class - ideally by creating a separate class for these advanced freshmen. He also suggests extensive use of open-ended activities, to encourage students to delve deeply and creatively into material. Finally, Roberts suggests providing an incentive system such as the increased opportunity to become undergraduate teaching assistants after successful completion of the advanced class.

The study presented in this paper combines these two areas of research on learning-by-teaching and on challenging first-year students, by using complex student module presentations in a first-term honors computing course. The term "capsules" conveys 
that student presentations "encapsulate" far more than a traditional lecture or tutoring session. The structural details of a capsule are described in Section 3. A primary motivation for this research is to inspire advanced first-year students to live up to their intellectual potential, in the hopes that they will persist in studies of computing. Towards this end, the primary research goals are to:

1. increase students' intrinsic motivation towards computing.

2. improve their research, oral communication, and teaming skills.

3. accomplish these skill improvements while deepening their understanding of course material.

This study differs from previous studies in that student presentations, especially of the complexity necessary for a capsule, have not been used for this purpose with advanced firstyear students. The results show that students were resistant to the paradigm shift in their learning and did not trust the capsule process. However, students reported that by being forced to develop capsules, they learned course content far better than they would have in a traditional lecture class. Capsule presentation also improved students' communication and teaching skills. Finally, students began to accept responsibility for their own learning.

\section{METHOD}

\subsection{Course Structure}

Student participants in this study were enrolled in one of three sections of CSSE221: Fundamentals of Software Development Honors in Fall, 2006. There were 35 students total; the section sizes were 15, 11, and 9. Students were placed into CSSE 221 through one of three avenues: Advanced Placement (AP) exam credit, a college placement exam score, or transfer credit. AP exams are national level, content specific, standardized tests often taken in the United States; college placement exams are institution level, content-specific standardized tests. The majority of students $(\mathrm{n}=21 ; 60 \%)$ were placed into the course via AP exam credit, $26 \%(\mathrm{n}=9)$ were placed via the college placement exam, while $11 \%(n=4)$ were placed via transfer credit. One student did not respond to the placement question. Student demographics for the 35 participants are given in Table 1 .

The technical focus of the course is object-oriented programming in Java, similar to CS2 in the objects-first, three-quarter sequence described in CC2001 [7]. The 10-week course outline is shown in Table 2. Student capsules are given in boldface and numbered. Instructor-led material preparing students to present capsules is given in italics.

The course utilizes a studio format, in which the class meets for 105 minutes, three times per week. Students bring their collegeissued laptops to each meeting. The instructors used the first meeting of the week to introduce a weekly programming project (weeks 1-3) or a larger team project (weeks 4 and 7) and to introduce topics needed for that particular project. An attempt was made to model diverse instructional methods, by varying the mix of lecture, demonstration, and student programming activities. From the very beginning of the term, the units of teaching and learning were referred to as capsules, to acclimate students to the method and vocabulary of the pedagogy.
Table 1. Participant Demographics

\begin{tabular}{|l|l|}
\hline Male & 34 \\
\hline Female Standing (by credits) & 1 \\
\hline \multicolumn{2}{|c|}{ Course of Study (Major) } \\
\hline Freshman & 30 \\
\hline Sophomore & 1 \\
\hline Junior & 1 \\
\hline \multicolumn{2}{|c|}{} \\
\hline Applied Biology & 1 \\
\hline Chemistry & 1 \\
\hline Chemical Engineering & 6 \\
\hline Computer Engineering & 12 \\
\hline Computer Science & 3 \\
\hline Electrical Engineering & 6 \\
\hline Mechanical Engineering & 2 \\
\hline Physics & 3 \\
\hline Software Engineering &
\end{tabular}

Table 2. Course Outline for CSSE221

\begin{tabular}{|c|l|}
\hline Wk. & \multicolumn{1}{|c|}{ Topics } \\
\hline 1 & $\begin{array}{l}\text { Environment (IDE, version control, unit testing), APIs, } \\
\text { writing to a specification, intro to big-Oh, exception } \\
\text { handling. Discuss how to prepare and present material. }\end{array}$ \\
\hline 2 & $\begin{array}{l}\text { UML, pair programming, inheritance (1), } \\
\text { polymorphism, abstract classes and interfaces (2), } \\
\text { debugging (3), debrief. }\end{array}$ \\
\hline 3 & $\begin{array}{l}\text { Arrays and array lists, GUI design using Swing (4), } \\
\text { Event-driven programming (5), applets (6), debrief. }\end{array}$ \\
\hline 4 & $\begin{array}{l}\text { Introduce database project, exam 1 (night), Queries and } \\
\text { SQL (7), searching algorithms and their efficiency (8), } \\
\text { simple sorting algorithms and efficiency (9), debrief. }\end{array}$ \\
\hline 5 & $\begin{array}{l}\text { Project work, including student presentation of screen } \\
\text { layouts to class. }\end{array}$ \\
\hline 6 & Project, file I/O (10), advanced GUI topics (11), debrief. \\
\hline 7 & $\begin{array}{l}\text { Intro network project, project time, threads (12), linked } \\
\text { lists (13), debrief. }\end{array}$ \\
\hline 8 & $\begin{array}{l}\text { Project time, generics (14), stacks and queues (15), } \\
\text { advanced linked lists (16), debrief. }\end{array}$ \\
\hline 9 & $\begin{array}{l}\text { Student Selected Topics: Graphics2D (17), Animation } \\
\text { (18), Inner Classes (19) debrief, project time, exam 2 } \\
\text { (night), status report presentations. }\end{array}$ \\
\hline 10 & Status report presentations, project time. \\
\hline
\end{tabular}




\section{Know your goal}

\section{How to Create a Capsule}

You should receive a list of questions from your instructor that your classmates are expected to be able to answer once they complete your capsule. One definition of "teach" is "to cause to learn". This is one way you should measure your teaching: did your classmates learn enough to answer the questions? (But you should not hand out these questions in class.)

Your task is to figure out how to accomplish this goal within the specified time limit (for example, 40 mins).

\section{Constraints}

1. Time limit: may depend on the capsule.

2. Team Participation: every member of your team must contribute to the preparation and delivery of your capsule.

3. Activity: you must design an activity to engage the class.

4. Assessment: you must have some method of determining during delivery if you are meeting your goal (i.e., are your classmates learning enough to be likely to answer the questions?)

5. Additional questions: you will also add 1-2 questions to the homework, which you will pass out in class.

\section{Prepare. Ask yourself these questions:}

1. Do I myself understand the material to be taught?

2. How can I motivate the problem?

3. What are the key concepts my classmates need to learn?

4. How can my classmates learn this material best? (discuss!)

5. How can I get feedback during this time that they understand it?

Prepare your materials. Practice your delivery (we can guarantee that if you don't plan, this will be way off)!

\section{Deliver to the class}

We'll expect each person in the team to contribute to the delivery of the capsule in some way.

\section{Deliverables to instructors.}

Checklist of who did what.

\section{Grading}

You will be graded on effort, organization, creativity, participation, and classmates' learning

\section{Figure 1. Capsule Preparation Handout}

Sessions 2 and 3 of each week were each divided in half, leaving four 50-minute blocks. The instructor typically used either two or three of these blocks for student presentations, allowing 40 minutes for each presentation, with a short time at the end of class to debrief. Any remaining class time was used for in-class project work.

During Week 1, the instructors led a 30-minute discussion of how the students could prepare and present capsules to their peers. This training encouraged the students to use a format that mirrored that of the instructors, within the context of a welldefined structure. In particular, students were encouraged to begin each capsule with a short introductory lecture on important vocabulary and concepts, followed by a demonstration (usually of code), and concluding with a hands-on activity. In addition, presenters were directed to monitor their classmates' learning and to develop varied methods of assessing content learning. A supplementary handout given to students at this time is shown in Figure 1.

Students presented capsules in groups of 3 , rotating into different teams for each new capsule. Each student presented 3 or 4 capsules over the 10 -week term. Students were evaluated by the instructor using a rubric that included the criteria given in Table 3. For each criterion, students were given a score of 1 (lowest) to 5 (best), and the weighted sum of the scores was used as the students' grade. Because the instructors did not present the rubric to the students before their first capsule presentation, and because they anticipated that students' presentations would improve over time, the lowest capsule grade was dropped. The remaining capsules were equally weighted and contributed a total of $25 \%$ of each student's grade in the course.

The instructors provided detailed written and verbal feedback to each group. Written feedback took the form of commendations and suggestions for improvement written on the rubric form. This information included a summary of written feedback from the audience (their peers and an undergraduate teaching assistant). Verbal feedback consisted of a debriefing session at the end of each week in which capsules were presented (see items in italics in Table 2). This feedback was not aimed at single groups, but to the class as a whole, focusing on how well the presentations were developing over the length of the course, and asking students for 
their impressions. An important goal of the verbal feedback sessions was to help students identify successful aspects of capsules so that they could incorporate those ideas into the next week's capsules. As the term progressed, debriefing also provided the opportunity to air concerns and then discuss strategies for preparation and time management.

Table 3. Criteria for Evaluating Student Presentations

\begin{tabular}{|l|l|r|}
\hline Criterion & Description & Weight \\
\hline Purpose & $\begin{array}{l}\text { Clearly provided motivation and } \\
\text { context to the capsule topic }\end{array}$ & $5 \%$ \\
\hline Explanation & Explained the material clearly & $10 \%$ \\
\hline Demo & $\begin{array}{l}\text { Gave understandable } \\
\text { demonstration of the capsule topic }\end{array}$ & $15 \%$ \\
\hline $\begin{array}{l}\text { Hands-on } \\
\text { Activity }\end{array}$ & $\begin{array}{l}\text { Actively engaged the class in the } \\
\text { capsule material }\end{array}$ & $15 \%$ \\
\hline Organization & $\begin{array}{l}\text { Organized presentation in a manner } \\
\text { that enhanced the audience's } \\
\text { understanding }\end{array}$ & $15 \%$ \\
\hline $\begin{array}{l}\text { Visual } \\
\text { Materials }\end{array}$ & $\begin{array}{l}\text { Used clear visual aids, provided useful } \\
\text { handouts, or employed other tangible } \\
\text { supplements }\end{array}$ & $\begin{array}{l}\text { Used the full allotted time well, and } \\
\text { distributed time among team members } \\
\text { equitably }\end{array}$ \\
\hline Time & $\begin{array}{l}\text { Faced and made eye contact with } \\
\text { members of the audience, words and } \\
\text { phrases enunciated well, kept tabs on } \\
\text { audience reactions; upbeat attitude }\end{array}$ & $10 \%$ \\
\hline $\begin{array}{l}\text { Presentation } \\
\text { Skills }\end{array}$ & $\begin{array}{l}\text { Used some method of finding out how } \\
\text { well audience was learning; assessed } \\
\text { both naturally verbal students as well } \\
\text { as more shy students }\end{array}$ & $10 \%$ \\
\hline Assessment Learning \\
\hline
\end{tabular}

\subsection{Study Protocol}

The students in CSSE221 were administered a background and post-course survey to assess the impact of the student-taught capsules. This research was conducted while the first and second authors were both instructors at Rose-Hulman; the surveys were developed with the assistance of Rose-Hulman's Office of Institutional Research, Planning and Assessment (IRPA), and with IRB Human Subject Study approval.

The background questionnaire consisted of nine questions which addressed students' levels of comfort with and experience in working in teams, teaching course content, and making an oral presentation. Other items included student ratings of predicted capsule enjoyment, enthusiasm in learning more about computing, and which venue they used for placement in the honors section (Appendix A). The post-course survey consisted of the same eight items as the pre-course survey for comfort, experience, capsule enjoyment, and enthusiasm for computing. There was also an item on the usefulness of student evaluations as well as four openended questions to gain more feedback on the benefit of the student-taught capsules (Appendix B).

Thirty-five students participated in the background survey while thirty-two students participated in the post-course survey. Participation was optional and the instructors did not know which students chose to participate. Aside from introducing the project, at no time did the instructors discuss the surveys or responses with the students. IRPA stored the surveys until end-of-term grades had been reported.

Closed-form questions were analyzed first by assembling demographic data, then conducting frequencies and mean of student responses. Finally, an Independent Samples T-Test was conducted to compare the mean scores between background and post-course responses. Open-ended questions were analyzed using a thematic approach developed by Miles \& Huberman [21]. The process is summarized as follows:

1) All of the survey responses were selected for coding in order to avoid bias in selection.

2) An independent researcher from another institution (the third author) with extensive experience in qualitative data analysis was brought in as an equal participant in data evaluation.

3) All of the survey responses were read and analyzed independently by the three researchers: the two RoseHulman instructors who taught the sections, and the independent researcher.

a. Each researcher developed codes, operational definitions, and themes grounded in the textual responses.

b. The three researchers compared their coding and thematic decisions. When there were divergent findings, only those encodings were retained in which all researchers could agree. An inter-rater reliability rating of $97 \%$ was achieved.

4) Twenty-one final codes with operational definitions were agreed upon, grouped into 5 categories: Communication, Content, Motivation, Perception, Teamwork (Appendix C). Three themes emerged, and are described in Section 4.2.

Additional data was collected in the form of peer evaluations and instructor journals. Peer evaluations were collected from each student who was on the receiving end of a capsule. Student presenters were evaluated on such factors as general presentation skills, specific oral communication skills, and their ability to cause their classmates to understand the material. Peer evaluations had three purposes. First, they were intended to provide presenters with feedback beyond that from their instructor. Second, they were intended to motivate students to think more deeply about the relationship between their experience as student and their experience as teacher. Third, the peer evaluations served the more mundane purpose of ensuring that students paid attention.

Instructor journals were maintained as personal observations of the capsule process as it unfolded. The purpose of the journals was two-fold. First, the journals recorded important pedagogical observations and classroom issues that might be forgotten. Second, the journals were intended to provide post-course hindsight about where the instructors picked up on or missed important student experiences recorded in the surveys. 


\section{RESULTS}

\subsection{Background and Post-Course Comparisons - Closed Form Questions}

Students reported statistically significant improvement in several areas targeted by this study (Table 4). As expected and hoped, experience and comfort levels working on a team improved $(\mathrm{t}=$ $-2.62, \mathrm{df}=65, \mathrm{p}<.05)(\mathrm{t}=-2.25, \mathrm{df}=65, \mathrm{p}<.05)$ as did experience teaching course content $(\mathrm{t}=-3.12$, $\mathrm{df}=65, \mathrm{p}<.05)$. Likewise, experience and comfort making oral presentations improved $(\mathrm{t}=-2.07, \mathrm{df}=65, \mathrm{p}<.05),(\mathrm{t}=-2.21, \mathrm{df}=65, \mathrm{p}<.05)$. Student comfort levels teaching course content increased, but not significantly. Unfortunately, student enjoyment of capsules declined significantly from their own pre-course predictions $(\mathrm{t}=$ $2.01, \mathrm{df}=65, \mathrm{p}<.05)$. Sections 4.2 and 5 discuss some possible reasons for this result. Finally, enthusiasm for computing declined significantly as well $(t=2.27, d f=64, p<.05)$. Although clearly disappointing, in hindsight this last result is not surprising given the centrality of the capsule experience to the CSSE221 class.

On the post-course survey, students were asked also to rate the usefulness of completing evaluations of student presenters in terms of their own learning. Instructors initially intended to distribute these peer evaluations to the presenters verbatim. Unfortunately this plan had to be changed because some students repeatedly used the anonymity to make highly critical and personal comments. In addition, some students appeared not to take the evaluations seriously, because they consistently provided all perfect or all negative feedback. Informal attempts to help students make constructive critiques were only partially successful. Rather than censor or withhold some of the evaluations, the instructors decided to summarize peer feedback as part of the debriefing sessions. Thus, it is perhaps not surprising that students did not find the peer evaluations particularly useful for their own learning $(\mathrm{M}=1.50)$.

Table 4. Background and Post-Course Survey Means

\begin{tabular}{|l|c|c|}
\hline \multicolumn{1}{|c|}{ Item } & Background & Post \\
\hline Comfort in working in a team* & 2.86 & 3.28 \\
\hline Experience in working in a team* & 2.69 & 3.22 \\
\hline Comfort teaching course content & 2.66 & 3.00 \\
\hline Experience teaching course content* & 2.17 & 2.81 \\
\hline Comfort making oral presentations* & 2.89 & 3.31 \\
\hline $\begin{array}{l}\text { Experience oral } \\
\text { presentations* making }\end{array}$ & 2.89 & 3.25 \\
\hline Capsule enjoyment* & 2.74 & 2.22 \\
\hline Computer Science enthusiasm* & 3.41 & 2.94 \\
\hline
\end{tabular}

Note: ${ }^{*}$ statistically significant differences in means, $\mathrm{p}<.05$.

\subsection{Open Ended Questions}

The students' responses to the capsule experience were characterized by three themes: resistance to change, lack of trust in the process, and increased ownership as learners. These themes cut across all responses, regardless of whether they were answering questions about the benefits or drawbacks of capsules, the effect of capsules on their understanding of material, or discussing a capsule-related topic of their own choosing.

Student resistance to change was expressed as a reaction to being placed in a learning environment that was new to them, and which directly challenged their paradigm of learning. In particular, although virtually every student felt that having to teach capsules significantly improved their own understanding of the material, they often questioned the benefit of their experience. For example, the following two comments are typical student responses about their learning: "When I taught a topic I found that I learned even more than I would have just on the student side", and "I understood the capsules I taught much more than usual". In tandem with these positive types of comments were ambivalent or outright negative comments such as the following examples: "I was forced to research that topic in more depth than usual", "[capsules were] an inefficient use of time", or "I would much rather have a professor teach the class. That is what I am paying to come here for".

Lack of trust in the process of developing and delivering capsules was prevalent among respondents. Analysis showed that students were uncomfortable with the ambiguity and uncertainty of having primary control of their learning shifted from the instructor to themselves. This discomfort was expressed through a desire for conventional instructor-led lectures, concrete guidelines about how they would be assessed, and a lack of confidence in content taught by their peers. For example, "[I have a] tendency not to pay attention", "It is very useful yet risky", "Really let us know what needs to be taught and that its [sic] correct", and finally, "no one gets a perfect grade, meaning some part of the teaching is not satisfactory without a professor teaching".

Interestingly, in spite of resisting and distrusting the experience of capsule learning, analysis showed that students increased their ownership as learners - a primary requirement for becoming an effective and creative problem solver. Respondents became more confident in their ability to take control of their own learning, and acknowledged maturing on many levels. For example, one student said "I got better experience which helps me teach others and help other students with CS or other areas". Other students responded, "I learned to make sure I know what I'm doing before I give a presentation", and "[A benefit of the capsule experience was] selfteaching ability". Yet another student responded, "It grew on me. I hated the idea for the first few [capsules], but by the end, I was trying to find interesting ways to do things".

\subsection{Journal Evaluations}

After the completion of the statistical analysis, and the establishment of codes and themes, the instructors reviewed their journals. Some student-generated themes were clearly foreshadowed in the journal entries, such as concerns with workload, and improvements in presentation skills and content knowledge derived from having to teach subject matter. However, there were some areas in which the instructors' perceptions diverged notably from the students' perceptions. In particular, at several points during the term the instructors perceived greater benefits from the capsule process than the students perceived. For example, the instructors saw a much greater increase in creativity and effectiveness teaching difficult course content than the students appeared to have given themselves credit for, based upon their recorded comments. Perhaps this finding is not surprising, 
given how difficult it can be for anyone (instructor, student, or otherwise) to see themselves change over time.

The instructors misread student reactions in some important places. Most significantly, the instructor journal entries did not recognize that many students were losing confidence in the process of capsules, even while they improved at developing and delivering them. While the instructors recognized as early as the third week that the students were spending a lot of time preparing capsules and were concerned about their grades, the journal entries do not recognize the magnitude of discomfort experienced by students. For example, one journal entry from Week 3 quoted a student comment: "(we're) not sure of the goal, what to emphasize, or the depth of what we should present", and responded with the following note-to-self: "my thought toward us improving the course next time is that we should give more structure on the earlier capsules to complement the list of questions we hand out."

Even more pointed is the following entry, also from Week 3, capturing a student quote: "The presenting group comes out on top, because they studied (the topic) the longest." Only much later did the instructor note: "[I] missed the underlying statement that the students in the audience felt they came out on the bottom. "

On the other hand, instructor journals clearly reflect an important pedagogical benefit of the capsule process: students having difficulty, whether because of attitude, other commitments, or content knowledge, rose very quickly to their attention. Within two weeks of starting the capsule process, the instructors were able to identify and target students who needed extra help. One of the journals in particular contains many extensive and detailed entries where the instructor works with students on problems that were unearthed from observing the capsule process.

\section{DISCUSSION}

The results of this study show that two of the primary pedagogical goals were achieved: first-year advanced students increased their ability to be self-directed researcher-learners of complex material, and they gained experience and confidence in their presentation, communication, and teaming skills. On the other hand, their enthusiasm for computing declined.

At first glance, these results might appear contradictory or perhaps confusing; however an examination of the data in light of the student population provides insight. The students were virtually all freshmen, and has been noted in many studies, the first year of college is often a shock and disillusionment for students. Their confidence and academic ability are challenged, along with their expectations for what it takes to be a successful student (an excellent survey of the literature on student expectations is contained in Howles [15]). Complicating matters further, their academic maturity may exceed their social maturity. In fact, it has been proposed that college-age students pass through formal developmental stages towards becoming selfreflective thinkers, independently from their cognitive development and irrespective of the concrete skills they acquire [17]. If this theory is valid, then there should be some ways to help students become more comfortable with the process of capsules, by actively directing course development towards moving them forward as reflective learners.

It is probably true that no matter what instructors do, many students are going to feel discomfort when their pre-conceived notions of how "teaching and learning work" are challenged. Recall that in his now classic work on paradigm change, Kuhn [20] discussed how scientists (and by extension presumably, people in general) strongly and stubbornly resist change to their worldviews. People on the receiving end of change are naturally predisposed to challenge and deflect radical new ideas until eventually they are forced to see their benefits. It takes a crisis and social pressure to precipitate acceptance of a new way of doing things. Thus with hindsight it is not surprising that CSSE221 students, among the most successful and brightest of their peers, reacted so strongly against a new paradigm of learning.

Indeed, there is some concrete evidence for this interpretation of student reactions. A fascinating study by Allert [1] showed a statistically significant correlation between students who highly value lectures as the primary delivery mode and who are the highest achievers.

Clearly, the CSSE221 capsule experience accomplished some of its most important pedagogical goals in spite of the issues just discussed. These accomplishments must be retained and enhanced in the next iteration of the course. In addition, there are several promising ways to address the challenges that surfaced during this first offering of the class. Primarily, it is important to acknowledge concerns about course structure and assessment that interfere with student appreciation of their own learning and other accomplishments. This can be done in several ways. For example, one could increase the visible course structure and presence of the instructors by introducing the capsule process incrementally. In particular, instructors should provide the greatest structure early on, gradually increasing the challenge and risk perceived by the students [6][16][23]. Ways to increase visible course structure include directly modeling the desired behaviors and providing written, detailed guidance on pedagogy, and assessment.

Small changes can make a difference, such as maintaining the same members across capsules so that students can develop behavioral norms and maintenance behaviors [29]. Another idea is to alter the capsule format to promote individual bonding between capsule presenters and their audience. Previous work has shown that when peer teachers form a positive affective connection with their student recipients, both teaching and recipient learning improves [10][23]. Bonding over the delivery of content should improve trust and motivation, thereby reducing stress and negative affective reactions. Perhaps, if instructors do not stress the "difference" aspects of the capsule process it would reduce anticipatory anxiety. These suggestions are only a start, and additional ideas for reducing anxiety and increasing the appearance of "normality" of the capsule process are needed.

\section{CONCLUSION}

The results reported in this paper provide a new perspective on the needs of a sometimes neglected group of first-term computing students: the experienced, highly prepared freshman. A group of traditionally well-prepared science and engineering freshmen were directed to research and develop complex teaching "capsules" for their peers. The results show that the students rose to the challenge, developing creative instructional materials about difficult computing topics. Students reported improving their content knowledge and soft skill development in many areas, more than they would have in the more familiar lecture 
environment. On the other hand, results demonstrate that students resented this new approach to classroom learning, as it challenged their preconceived ideas about how classroom instruction should operate. This resistance to change led to a reduced motivation towards computing studies. These data suggest that instructors should adjust the course structure to provide greater guidance and an appearance of "normalcy", thus reducing anxiety in the otherwise successful capsule process.

\section{ACKNOWLEDGMENTS}

The authors would like to thank Shannon Sexton for performing the statistical analyses.

\section{REFERENCES}

[1] Allert, James D. The effectiveness of innovative approaches to CS1: Comparing opinion to outcome. In Proceedings of the $27^{\text {th }}$ Australasian Computer Sciences Conference. (Dunedin, New Zealand, 2004), 151-157.

[2] Bargh, J. A. and Schul, Y. The cognitive benefits of teaching. Journal of Educational Psychology, 72 (1980), 593-604.

[3] Bayliss, Jessica D. and Strout, Sean. Games as a "flavor" of CS1. In Proceedings of the Thirty-Seventh SIGCSE Technical Symposium on Computer Science Education (Houston, Texas, USA, March 1-5, 2006), 500-504.

[4] Benware, C. A. and Deci, E. L. The quality of learning with an active versus passive motivational set. American Educational Research Journal, 21 (1984), 755-766.

[5] Bruce, Kim B. Attracting (\& keeping) the best and the brightest: An entry-level course for experienced introductory students. In Proceedings of the Twenty-Fifth SIGCSE Technical Symposium on Computer Science Education (Phoenix, Arizona, USA, 1994), 243-247.

[6] Carbone, Angela. Attracting and retaining the best students A first year advanced students' project scheme. In Proceedings of the Second Australasian Computing Education Conference (Melbourne, Australia, July 2 - 4, 1997), 141-148.

[7] CC2001 Task Force. Computing Curricula 2001: Computer Science Volume. Retrieved April 29, 2007 from http://www.sigcse.org/cc2001/.

[8] Carter, Lori. Why students with an apparent aptitude in computer science don't choose to major in computer science. In Proceedings of the Thirty-Seventh SIGCSE Technical Symposium on Computer Science Education (Houston, Texas, USA, March 1-5, 2006), 27-31.

[9] Cassel, Lillian, et al. Special Session. The current crisis in computing: What are the real issues? In Proceedings of the Thirty-Eighth SIGCSE Technical Symposium on Computer Science Education (Covington, Kentucky, USA, March 7-10, 2007), 329-330.

[10] Ching, E., Chen, C.-T., Chou, C.-Y., Deng, Y.-C., and Chan, T.-W. A pilot study of computer supported learning by constructing instruction notes and peer expository instruction. In Proceedings of the 2005 Conference on Computer Support for Collaborative Learning: learning 2005: the next 10 years! (Taipei, Taiwan, 2005), 63-67.
[11] Dankel, Douglas D. II, and Ohlrich, Jonathan. Students teaching students: Incorporating presentations into a course. In Proceedings of the Thirty-Eighth SIGCSE Technical Symposium on Computer Science Education (Covington, Kentucky, USA, March 7-10, 2007), 96-99.

[12] Falchikov, Nancy. Learning Together: Peer Tutoring in Higher Education. Routledge Falmer, London, UK, 2001.

[13] Gonzalez, Graciela. A systematic approach to active and cooperative learning in CS1 and its effects on CS2. In Proceedings of the Thirty-Seventh SIGCSE Technical Symposium on Computer Science Education (Houston, Texas, USA, March 1-5, 2006), 133-137.

[14] Gruba, Paul and Al-Mahmood, Reem. Strategies for communication skills development. In Proceedings of the Sixth Australasian Computing Education Conference (Dunedin, New Zealand, 2004), 101-107.

[15] Howles, Trudy. Preliminary results of a longitudinal study of computer science student trends, behaviors and preferences. Journal of Computing Sciences in Colleges. 22,6 (2007), 1827.

[16] Kaczmarczyk, Lisa C., Last, Mary Z. and Miikkulainen, Risto. The effect of delivery method on conceptual and strategy development. In Proceedings of the $28^{\text {th }}$ Annual Conference of the Cognitive Science Society (Vancouver, British Columbia, July 26 - 29, 2006).

[17] King, Patricia M. and Strohm Kitchener, Karen. Developing Reflective Judgment. Jossey-Bass, San Francisco, CA, 1994.

[18] Kinnunen, Päivi and Malmi, Lauri. Why students drop out CS1 course? In Proceedings of the 2006 International Education Research Workshop (Canterbury, UK, September 9-10, 2006), 97-108.

[19] Kuhn, Thomas S. The Structure of Scientific Revolutions. $2^{\text {nd }}$ Edition. The University of Chicago, Chicago, IL, 1970.

[20] Lui, Chang. Using tracking tools to facilitate student learning of communication skills in software engineering courses. $18^{\text {th }}$ Conference on Software Engineering Education and Training (CSEET) (Ottawa, Canada, April 18-20, 2005), 6168.

[21] Miles, Matthew B. and Huberman, A. Michael. Qualitative Data Analysis. $2^{\text {nd }}$ Edition. Sage, Thousand Oaks, CA, 1994.

[22] Oborne, Lawrence. Thinking, speaking, writing for freshmen. In Proceedings of the Thirty-Seventh SIGCSE Technical Symposium on Computer Science Education (Houston, Texas, USA, March 1-5, 2006), 112-116.

[23] Okita, Sandra Y. and Schwartz, Daniel L. When observation beats doing: Learning by teaching. In Proceedings of the $7^{\text {th }}$ International Conference on Learning Sciences (Bloomington, IN, USA, 2006), 509-515.

[24] Plimmer, Beryl and Amor, Robert. Peer teaching extends HCI learning. In Proceedings of the $11^{\text {th }}$ SIGCSE Annual Conference on Innovation and Technology in Computer Science Education (Bologna, Italy, June 26-28, 2006), 5357.

[25] Pollack, Lori. Integrating an intensive experience with communications skills development into a computer science course. In Proceedings of the 32nd SIGCSE Technical 
Symposium on Computer Science Education (Charleston, North Carolina, USA, 2001), 287-291.

[26] Rao, M.R.K. Krishna. Infusing critical thinking skills into content of AI course. In Proceedings of the $10^{\text {th }}$ SIGCSE Annual Conference on Innovation and Technology in Computer Science Education (Monte de Caparica, Portugal, June 27-29, 2005), 173-177.

[27] Reges, Stuart. Back to basics in CS1 and CS2. In Proceedings of the Thirty-Seventh SIGCSE Technical Symposium on Computer Science Education (Houston, Texas, USA, March 1-5, 2006), 293-297.

[28] Roberts, Eric. Strategies for encouraging individual achievement in introductory computer science courses. In Proceedings of the Thirty-First SIGCSE Technical Symposium on Computer Science Education (Austin, Texas, USA, 2000), 295-299.

[29] Ryan, Sherry D., Bordoloi, Bijoy, and Harrison, David A. Acquiring conceptual data modeling skills: The effect of cooperative learning and self-efficacy on learning outcomes. The DATA BASE for Advances in Information Systems, 31, 4 (Fall, 2000), 9-24.

[30] Sabin, R. E. and Sabin, E. P. Collaborative learning in an introductory computer science course. SIGCSE Bulletin, 23, 1 (1994), 304-308.

[31] Secretary's Commission on Achieving Necessary Skills. What work requires of schools: A SCANS report for America 2000 . Washington DC: U.S. Department of Labor, 1991. Retrieved April 29, 2007, from http://wdr.doleta.gov/SCANS/whatwork/.

\section{APPENDIX A: BACKGROUND QUESTIONNAIRE}

1. Please rate your comfort in working in a team for a class project before starting this class.

$\begin{array}{cccc}1 & 2 & 3 & 4 \\ \text { Very } & \text { Uncomfortable } & \text { Comfortable } & \begin{array}{c}\text { Very } \\ \text { Uncomfortable }\end{array}\end{array}$

2. Please rate your experience in working on a team for a class project before starting this class.

$\begin{array}{ccccc}0 & 1 & 2 & 3 & 4 \\ \text { None } & \text { Very Little } & \text { Little } & \text { Much } & \text { A Great Deal }\end{array}$

3. Please rate your comfort in teaching course content to classmates before starting this class.

$\begin{array}{cccc}1 & 2 & 3 & 4 \\ \text { Very } & \text { Uncomfortable } & \text { Comfortable } & \begin{array}{c}\text { Very } \\ \text { Uncomfortable }\end{array}\end{array}$

4. Please rate your experience in teaching course content to classmates before starting this class.

$\begin{array}{lcccc}0 & 1 & 2 & 3 & 4 \\ \text { None } & \text { Very Little } & \text { Little } & \text { Much } & \text { A Great Deal }\end{array}$

5. Please rate your comfort in making an oral presentation before starting this class.

$$
\begin{array}{cccc}
1 & 2 & 3 & 4 \\
\text { Very } & \text { Uncomfortable } & \text { Comfortable } & \begin{array}{c}
\text { Very } \\
\text { Comfortable }
\end{array}
\end{array}
$$

6. Please rate your experience in making an oral presentation before starting this class.

$$
\begin{array}{ccccc}
0 & 1 & 2 & 3 & 4 \\
\text { None } & \text { Very Little } & \text { Little } & \text { Much } & \text { A Great Deal }
\end{array}
$$

7. How well do you think you will enjoy the capsule class format compared to the traditional class format of you other courses at RHIT?

$\begin{array}{lcccc}1 & 2 & 3 & 4 & 5 \\ \text { Much } & \text { Less } & \begin{array}{c}\text { About } \\ \text { the Same }\end{array} & \text { More } & \text { Much } \\ \text { Less } & & & \text { More }\end{array}$

8. At the start of this class, how enthusiastic were you to learn more about computer science.

$\begin{array}{cccc}1 & 2 & 3 & 4 \\ \text { Very } & \text { Unenthusiastic } & \text { Enthusiastic } & \text { Very } \\ \text { Unenthusiastic } & & & \text { Enthusiastic }\end{array}$

9. Which of the following tools did you use for placement in CSSE221?

AP credit

RHIT placement exam

Transfer credit

other, please specify

\section{APPENDIX B: POST-COURSE QUESTIONNAIRE}

1. Please rate your comfort in working on a team for a class project.

$\begin{array}{cccc}1 & 2 & 3 & 4 \\ \text { Very } & \text { Uncomfortable } & \text { Comfortable } & \begin{array}{c}\text { Very } \\ \text { Uncomfortable }\end{array} \\ & & & \text { Comfortable }\end{array}$

2. Please rate your experience in working on a team for a class project.

$\begin{array}{ccccc}0 & 1 & 2 & 3 & 4 \\ \text { None } & \text { Very Little } & \text { Little } & \text { Much } & \text { A Great Deal }\end{array}$

3. Please rate your comfort in teaching course content to classmates.

$\begin{array}{cccc}1 & 2 & 3 & 4 \\ \text { Very } & \text { Uncomfortable } & \text { Comfortable } & \begin{array}{c}\text { Very } \\ \text { Uncomfortable }\end{array} \\ & & & \text { Comfortable }\end{array}$

4. Please rate your experience in teaching course content to classmates.

$\begin{array}{ccccc}0 & 1 & 2 & 3 & 4 \\ \text { None } & \text { Very Little } & \text { Little } & \text { Much } & \text { A Great Deal }\end{array}$


5. Please rate your comfort in making an oral presentation.

$\begin{array}{cccc}1 & 2 & 3 & 4 \\ \text { Very } & \text { Uncomfortable } & \text { Comfortable } & \begin{array}{c}\text { Very } \\ \text { Comfortable }\end{array}\end{array}$

6. Please rate your experience in making an oral presentation.

$$
\begin{array}{ccccc}
0 & 1 & 2 & 3 & 4 \\
\text { None } & \text { Very Little } & \text { Little } & \text { Much } & \text { A Great Deal }
\end{array}
$$

7. How well did you enjoy the capsule class format compared to the traditional class format of you other courses at RHIT?

$\begin{array}{lcccc}1 & 2 & 3 & 4 & 5 \\ \text { Much } & \text { Less } & \begin{array}{c}\text { About } \\ \text { the Same }\end{array} & \text { More } & \text { Much } \\ \text { Less } & & & \text { More }\end{array}$

8. How enthusiastic are you to learn more about computer science after this course?

$\begin{array}{cccc}1 & 2 & 3 & 4 \\ \text { Very } & \text { Unenthusiastic } & \text { Enthusiastic } & \text { Very } \\ \text { Unenthusiastic } & & & \text { Enthusiastic }\end{array}$

9. In terms of your learning, how useful was filling out evaluations for each presenter?

$\begin{array}{cccc}1 & 2 & 3 & 4 \\ \text { Not at all } & \text { Somewhat } & \text { Useful } & \text { Very } \\ \text { Useful } & \text { Useful } & & \text { Useful }\end{array}$

10. In what ways did teaching a capsule impact your understanding of that topic?

11. What benefits did you get from the capsule experience?

12. What drawbacks did you perceive in the capsule experience?

13. What else would you like to tell us about the capsule experience?

\section{APPENDIX C: CODES AND OPERATIONAL DEFINITIONS}

\begin{tabular}{|c|c|}
\hline $\begin{array}{l}\text { Content - } \\
\text { I Teach, I Learn }\end{array}$ & $\begin{array}{l}\text { Students teach a topic and learn more } \\
\text { about the topic as a result. }\end{array}$ \\
\hline $\begin{array}{l}\text { Content- } \\
\text { I Teach, Not } \\
\text { Helpful }\end{array}$ & $\begin{array}{l}\text { Students teach a topic and don't learn } \\
\text { well. }\end{array}$ \\
\hline $\begin{array}{l}\text { Content - } \\
\text { They Teach, I } \\
\text { Don't Learn }\end{array}$ & $\begin{array}{l}\text { Students do not learn as well when other } \\
\text { students teach a topic. }\end{array}$ \\
\hline $\begin{array}{l}\text { Motivation - } \\
\text { Creativity }\end{array}$ & $\begin{array}{l}\text { Students try interesting ways to do } \\
\text { things. }\end{array}$ \\
\hline $\begin{array}{l}\text { Motivation - } \\
\text { Decreased }\end{array}$ & $\begin{array}{l}\text { Students do not like some part of the } \\
\text { experience decreasing their motivation }\end{array}$ \\
\hline $\begin{array}{l}\text { Motivation - } \\
\text { Increased }\end{array}$ & $\begin{array}{l}\text { Students like at least some part of the } \\
\text { experience increasing their motivation }\end{array}$ \\
\hline $\begin{array}{l}\text { Motivation - } \\
\text { Learn to learn }\end{array}$ & $\begin{array}{l}\text { Students recognize that they gain ability } \\
\text { to teach themselves }\end{array}$ \\
\hline $\begin{array}{l}\text { Motivation - } \\
\text { Not pay } \\
\text { attention }\end{array}$ & $\begin{array}{l}\text { Students said it was harder to focus on } \\
\text { their classmates. }\end{array}$ \\
\hline $\begin{array}{l}\text { Motivation - } \\
\text { Self-Efficacy }\end{array}$ & $\begin{array}{l}\text { Students' confidence in themselves is } \\
\text { increased. }\end{array}$ \\
\hline $\begin{array}{l}\text { Perception - } \\
\text { Course Structure }\end{array}$ & $\begin{array}{l}\text { Students are concerned about grading, } \\
\text { availability of resources, and the } \\
\text { disconnect between the material } \\
\text { presented in the capsules and other } \\
\text { assessed aspects of the course } \\
\text { (homework, projects, and exams). }\end{array}$ \\
\hline $\begin{array}{l}\text { Perception - } \\
\text { MiscBenefit }\end{array}$ & $\begin{array}{l}\text { Students perceive some advantages with } \\
\text { the capsule experience. ( } 3 \text { pertained to } \\
\text { some aspect of variety: split out?) }\end{array}$ \\
\hline $\begin{array}{l}\text { Perception - } \\
\text { Misconception }\end{array}$ & $\begin{array}{l}\text { Students believe they are not being } \\
\text { taught. }\end{array}$ \\
\hline $\begin{array}{l}\text { Perception - } \\
\text { Need professor }\end{array}$ & $\begin{array}{l}\text { Students expressed a desire to have } \\
\text { some or all topics taught by a professor. }\end{array}$ \\
\hline $\begin{array}{l}\text { Perception - } \\
\text { No Benefit }\end{array}$ & $\begin{array}{l}\text { Students perceive no advantages with } \\
\text { the capsule experience. }\end{array}$ \\
\hline $\begin{array}{l}\text { Perception - } \\
\text { Time } \\
\text { Requirement }\end{array}$ & $\begin{array}{l}\text { Students feel that too much time was } \\
\text { required to prepare a capsule. }\end{array}$ \\
\hline $\begin{array}{l}\text { Perception - } \\
\text { Trust }\end{array}$ & $\begin{array}{l}\text { Students lacked confidence in the } \\
\text { accuracy of the material delivered by } \\
\text { other students. }\end{array}$ \\
\hline $\begin{array}{l}\text { Team Work - } \\
\text { Slackers }\end{array}$ & $\begin{array}{l}\text { Students are upset at the effect on their } \\
\text { learning of group members either in } \\
\text { their own team or other teams did not } \\
\text { pull their weight. }\end{array}$ \\
\hline
\end{tabular}

\begin{tabular}{|l|l|}
\hline Term & Definition \\
\hline $\begin{array}{l}\text { Communication } \\
\text { - Presentation }\end{array}$ & $\begin{array}{l}\text { Students learn how to communicate } \\
\text { material to a group in a presentation } \\
\text { format. }\end{array}$ \\
\hline $\begin{array}{l}\text { Communication } \\
\text { - Teaching }\end{array}$ & $\begin{array}{l}\text { Students improved their ability to teach } \\
\text { others. }\end{array}$ \\
\hline $\begin{array}{l}\text { Content } \\
\text { - Broad Impact }\end{array}$ & $\begin{array}{l}\text { Students describe an effect the capsules } \\
\text { had on the entire class, not just } \\
\text { themselves. }\end{array}$ \\
\hline $\begin{array}{l}\text { Content - } \\
\text { Forced to Learn }\end{array}$ & $\begin{array}{l}\text { Students preparing to teach the class } \\
\text { forced to learn more than they otherwise } \\
\text { would. }\end{array}$ \\
\hline
\end{tabular}

